\title{
Larval feeding habits of Diaphus theta, Protomyctophum thompsoni, and Tarletonbeania taylori (Pisces: Myctophidae) in the transition region of the western North Pacific
}

\author{
Chiyuki Sassa $^{1,2, *}$, Kouichi Kawaguchi $^{1}$ \\ ${ }^{1}$ Ocean Research Institute, University of Tokyo, 1-15-1 Minamidai, Nakano-ku, Tokyo 164-8639, Japan \\ ${ }^{2}$ Present address: Seikai National Fisheries Research Institute, Fisheries Research Agency, 1551-8 Taira-machi, \\ Nagasaki 851-2213, Japan
}

\begin{abstract}
We examined the larval feeding habits of the 3 dominant myctophids, Diaphus theta, Protomyctophum thompsoni, and Tarletonbeania taylori, in the transition region of the western North Pacific. Feeding incidence for $D$. theta and $T$. taylori larvae was higher during the day than at night (mean: 70.7 to $84.4 \%$ vs. 2.2 to $4.1 \%$ ), indicating that they are daytime visual feeders. Larvae of $P$. thompsoni were also visual feeders, with a daytime feeding incidence of $83.0 \%$. The proportion of nighttime feeding in $P$. thompsoni gradually increased with development, which suggests faster larval adaptation of this non-migrant species to the poor light conditions in the mesopelagic zone. $D$. theta larvae $\leq 7.9 \mathrm{~mm}$ in body length (BL) fed mainly on copepod nauplii, which were replaced by calanoid copepodites and Oithona spp. in larvae $\geq 8.0 \mathrm{~mm}$ BL. The most important prey for smaller P. thompsoni and $T$. taylori larvae $\leq 7.9 \mathrm{~mm}$ BL were nauplii and Oithona spp., which were replaced by calanoid copepodites and ostracods in $P$. thompsoni and copepod eggs in $T$. taylori with increased development. Competition for prey among the larvae of these 3 myctophids was mostly avoided because of diet and habitat-depth segregation. Interspecific comparisons of feeding habits among the 3 species, in addition to larvae of 3 other myctophids found in the study area, suggested that their feeding strategies were associated with mouth size, i.e. larvae with larger mouths tended to take larger prey rather than a large number of smaller prey. This interspecific difference in feeding strategy is reflected in the diverse morphological characters of myctophid fish larvae.
\end{abstract}

KEY WORDS: Myctophid fish larvae $\cdot$ Larval feeding habits $\cdot$ Diet composition $\cdot$ Niche breadth Larval mouth size $\cdot$ Resource partitioning $\cdot$ Transition region $\cdot$ Habitat segregation

\section{INTRODUCTION}

Worldwide, myctophid fishes comprise 32 genera that include ca. 240 species; they are the most speciose of the mesopelagic fish families (Bekker 1967, Paxton 1979, Moser \& Ahlstrom 1996). The morphology of myctophid larvae is quite diverse (Pertseva-Ostroumova 1964, Ozawa 1986, Moser \& Ahlstrom 1996), and almost all typical body forms of teleost larvae are represented among larval myctophids (Moser 1981). This diversity is related to the high variety of feeding habits among myctophid larvae, allowing the co-existence of many different species (Moser 1981, Sabatés \& Saiz 2000, Sassa et al. 2002b, Sassa \& Kawaguchi 2004). Body and mouth forms show various species-specific size ranges that allow prey-size partitioning among species.

The transition region of the western North Pacific is an important spawning and nursery ground not only for many commercial fish species but also for subarctic, 
transitional, and subtropical myctophid fishes (Sassa et al. 2004b). Two different mechanisms account for the occurrence of myctophid larvae in this region. Several subtropical species, such as Diaphus garmani and Myctophum asperum, and 1 transitional water species, Notoscopelus japonicus, spawn in the Kuroshio region, and their larvae are transported into the transition region by the Kuroshio Current (Sassa et al. 2002b, $2004 a, b)$, which usually occurs in the southern part of this region, south of the Oyashio Front (Sassa et al. $2004 \mathrm{~b})$. On the other hand, several subarctic species, including D. theta, Protomyctophum thompsoni, and Tarletonbeania taylori, which were investigated in this study, undergo a southward spawning migration from their feeding grounds in the subarctic waters to the transition region, and their larvae are found in the warm epipelagic layer of the transition region (Sassa 2001, Sassa et al. 2002a, 2004b, Moku et al. 2003). Larvae of subtropical and subarctic species sometimes mix in the southern part of the transition region owing to the complicated physical oceanographic structures there, such as warm water tongues or streamers, although the spawning grounds of subtropical and subarctic species are quite different. Based on the dominance of myctophid fish larvae in oceanic ichthyoplankton assemblages (Ahlstrom 1969, Loeb 1979a,b, Moser \& Smith 1993, Sassa et al. 2002b, 2004a), they have been regarded as potential competitors for prey with commercially important epipelagic fish larvae in the oceanic regions (Ahlstrom 1969, Sassa \& Kawaguchi 2004).

Diaphus theta, Protomyctophum thompsoni, and Tarletonbeania taylori are the dominant myctophid fishes in the transition and subarctic regions of the North Pacific (Bekker 1967, Wisner 1976, Pearcy et al. 1979, Willis et al. 1988, Beamish et al. 1999, Watanabe et al. 1999). The larvae of these species are distributed in the productive upper $200 \mathrm{~m}$ layer of the transition region, both during the day and at night (Sassa 2001, Tsukamoto et al. 2001). After transformation from larvae to juveniles, D. theta and T. taylori begin diel vertical migrations, while $P$. thompsoni shows no diel vertical migration and remains primarily in the upper mesopelagic layer at a depth of 200 to $400 \mathrm{~m}$ (Pearcy et al. 1977, Watanabe et al. 1999).

Recently, Sassa \& Kawaguchi (2004) described the larval feeding habits of the 2 subtropical species Diaphus garmani and Myctophum asperum in the transition region of the western North Pacific. Although nauplii through to adult stages of copepods are the typical food of myctophid fish larvae studied to date (Sabatés \& Saiz 2000), these 2 species depend much more on appendicularian houses and on ostracods and polychaetes, respectively, and show unique speciesspecific feeding habits (Sassa \& Kawaguchi 2004).
However, knowledge of the larval feeding habits of subarctic species in this region remains sparse.

In this study, we determined and compared the larval feeding habits of Diaphus theta, Protomyctophum thompsoni, and Tarletonbeania taylori in the transition region of the western North Pacific. Feeding incidence, diet composition, prey size, trophic niche breadth, numbers of prey items consumed, and the relationships between morphological variables (body length and mouth size) and feeding habits were examined. Interspecific differences among the feeding habits of these larvae, which are spawned in the transition region, together with 3 other common myctophid larvae that are spawned in the Kuroshio region and transported into the study area (Sassa 2001, Sassa \& Kawaguchi 2004), are discussed in relation to mouth size. Possible competition for prey among the larvae of the 3 myctophids and Japanese anchovy Engraulis japonicus is also discussed, since E. japonicus larvae are the most dominant among commercially important fish larvae in this study area and their habitats often overlap spatiotemporally (Kubota et al. 2001, Sassa 2001, Takahashi et al. 2001).

\section{MATERIALS AND METHODS}

Sample collection. Larvae were collected during 5 cruises in the transition region of the western North Pacific in 1997 and 1998 (Fig. 1, Table 1). At each station, daytime and/or nighttime samples were collected. Tows conducted between $1 \mathrm{~h}$ after sunrise and $1 \mathrm{~h}$ before sunset, and between $1 \mathrm{~h}$ after sunset and $1 \mathrm{~h}$ before sunrise, were considered 'daytime' and 'nighttime' samples, respectively.

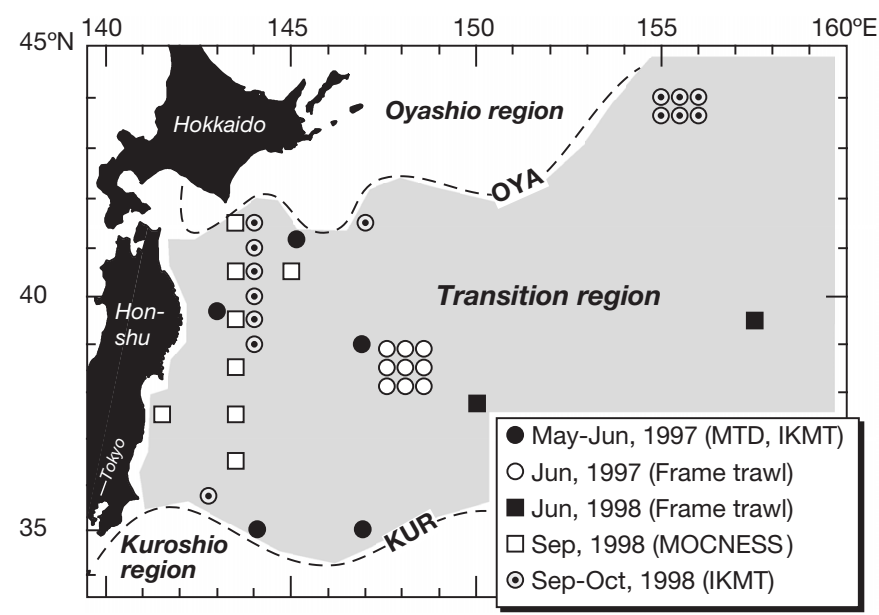

Fig. 1. Sampling localities of fish larvae during the 5 cruises in the transition region of the western North Pacific. The position of the Kuroshio (KUR) and Oyashio (OYA) fronts (broken lines) and water masses are shown 
Table 1. Diaphus theta, Protomyctophum thompsoni, and Tarletonbeania taylori. The numbers of individuals examined for gut contents. -: no larvae were caught or examined

\begin{tabular}{|lccc|}
\hline $\begin{array}{l}\text { Sampling } \\
\text { period } \\
\text { (Sampling gears) }\end{array}$ & $\begin{array}{c}\text { Diaphus } \\
\text { theta }\end{array}$ & $\begin{array}{c}\text { Protomycto- } \\
\text { phum } \\
\text { thompsoni }\end{array}$ & $\begin{array}{c}\text { Tarleton- } \\
\text { beania } \\
\text { taylori }\end{array}$ \\
\hline $\begin{array}{l}\text { May-Jun 1997 } \\
\text { (MTD, IKMT) }\end{array}$ & 45 & 10 & 26 \\
$\begin{array}{l}\text { Jun 1997 } \\
\text { (Frame trawl) }\end{array}$ & 77 & 17 & - \\
$\begin{array}{l}\text { Jun 1998 } \\
\text { (Frame trawl) }\end{array}$ & 28 & - & 22 \\
$\begin{array}{l}\text { Sep 1998 } \\
\text { (MOCNESS) }\end{array}$ & 3 & 26 & 4 \\
$\begin{array}{l}\text { Sep-Oct 1998 } \\
\text { (IKMT) }\end{array}$ & 19 & 104 & 70 \\
Total & 172 & 157 & 122 \\
\hline
\end{tabular}

Between 23 May and 15 June 1997, a multi-layer closing net with an $80 \mathrm{~cm}$ mouth diameter and a $0.5 \mathrm{~mm}$ mesh (MTD net, Motoda 1971) was towed for $30 \mathrm{~min}$ at depths within the upper $30 \mathrm{~m}$, and/or a $10 \mathrm{ft}$ Isaacs-Kidd midwater trawl (IKMT) fitted with a 0.5 or $1.0 \mathrm{~mm}$ mesh net was towed obliquely to sample depths within the upper $100 \mathrm{~m}$ during a cruise of the RV 'Hakuho-Maru' (Ocean Research Institute, University of Tokyo).

A rectangular frame trawl with a $2.24 \times 2.24 \mathrm{~m}$ mouth opening and $1.59 \mathrm{~mm}$ mesh net (MOHT net, Oozeki et al. 2004) was obliquely towed down to ca. $75 \mathrm{~m}$ during a cruise of the RV 'Soyo-Maru' (National Research Institute of Fisheries Science, Japanese Fisheries Agency) from 1 to 6 June 1997, and a cruise of the RV 'Wakataka-Maru' (Tohoku National Fisheries Research Institute, Japanese Fisheries Agency) from 7 to 9 June 1998.

During a cruise of the RV 'Wakataka-Maru' from 1 to 13 September 1998, vertically stratified samplings were made at 7 stations with a multiple-opening/closing net and an environmental sensing system, MOCNESS $(0.9 \times 1.3 \mathrm{~m}$ mouth opening; $0.33 \mathrm{~mm}$ mesh net; Wiebe et al. 1985), to sample 0-25, 25-50, 50-150, and 150-250 $\mathrm{m}$ depth strata during the daytime ( 7 tows) and at night (5 tows). During a cruise of the RV 'Hakuho-Maru' from 27 September to 23 October 1998, a 10 foot IKMT fitted with a $0.5 \mathrm{~mm}$ mesh net was obliquely towed to sample depths within the upper $250 \mathrm{~m}$. Plankton samples were fixed in $10 \%$ buffered formalin seawater at sea.

Fish larvae of the entire size range, from first-feeding to transformation stages, are very difficult to collect using 1 type of sampling gear owing to net extrusion of smaller larvae and net avoidance by larger. Therefore, we adopted 4 types of gear with different mesh sizes $(0.33,0.5,1.0$, and $1.59 \mathrm{~mm})$ and towing speeds (MTD and MOCNESS, 1.5 knots; IKMT, 2.5 knots; MOHT, 4.0 knots). For smaller larvae, we used the MTD and MOCNESS, and for larger larvae the IKMT and MOHT. Given the maximum body depth of larvae (Moser \& Ahlstrom 1996), net extrusion would occur for larvae $<4.3 \mathrm{~mm}$ in notochord length, even when using a $0.33 \mathrm{~mm}$ mesh net. There is no significant difference between day and night catchability of small myctophid larvae $<5 \mathrm{~mm}$ in body length (Sassa et al. 2002a, 2004a,c). On the other hand, larger larvae, especially those $>10 \mathrm{~mm}$ in standard length, may be able to avoid nets visually during daytime sampling, although the details of how they do this are unclear. We were able to pool the larvae of a wide size range from both daytime and nighttime samples (Fig. 2, Table 2), and the sampling limitations described above did not affect our assessment of general feeding habits.

Laboratory analyses. Intact specimens of Diaphus theta, Protomyctophum thompsoni, and Tarletonbeania taylori larvae were sorted for gut content analysis, and 172, 157, and 122 individuals were examined, respectively (Table 1). Before dissection, the body length (BL)

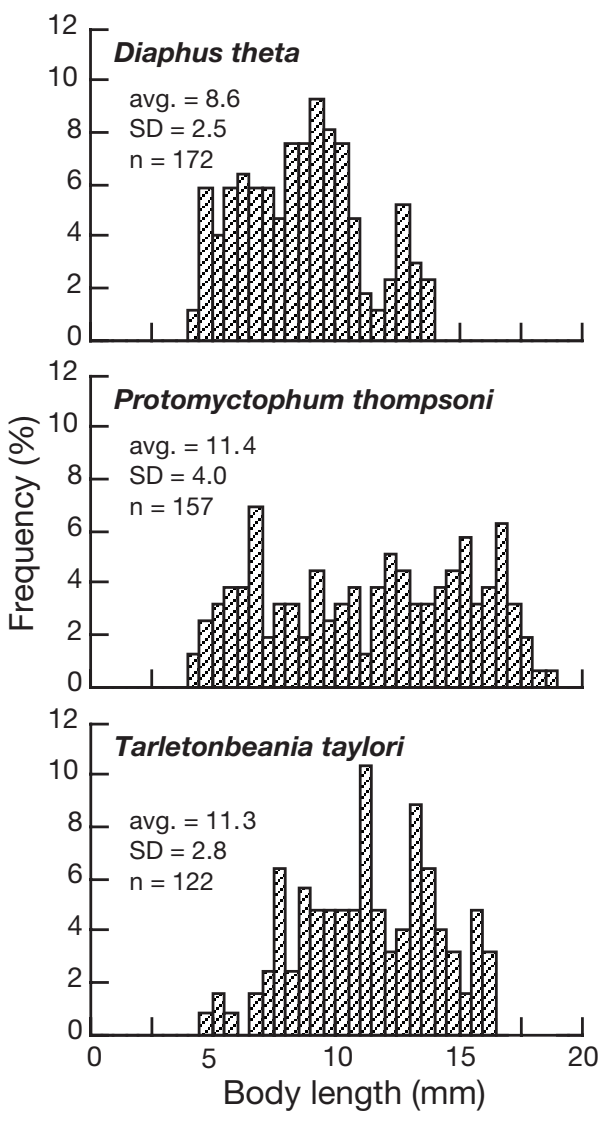

Fig. 2. Diaphus theta, Protomyctophum thompsoni, and Tarletonbeania taylori. Length-frequency distributions of the larvae examined for gut content analysis 
Table 2. Diel change in the feeding incidence (\%) of Diaphus theta, Protomyctophum thompsoni, and Tarletonbeania taylori larvae in the transition region of the western North

Pacific. BL: body length; N: number of larvae examined

\begin{tabular}{|lcrrrr|}
\hline \multirow{2}{*}{ Species } & \multirow{2}{*}{$\begin{array}{c}\text { Size class } \\
\text { (mm BL) }\end{array}$} & \multicolumn{2}{c}{ Day } & \multicolumn{2}{c|}{ Night } \\
& & $\mathrm{N}$ & \multicolumn{1}{c}{$\%$} & $\mathrm{~N}$ \\
\hline Diaphus & $4.8-7.9$ & 60.4 & 53 & 0.0 & 15 \\
theta & $8.0-11.9$ & 78.1 & 64 & 0.0 & 18 \\
& $12.0-13.8$ & 83.3 & 6 & 12.5 & 16 \\
& Total & 70.7 & 123 & 4.1 & 49 \\
Protomycto- & $4.3-7.9$ & 75.0 & 28 & 0.0 & 15 \\
phum & $8.0-11.9$ & 87.5 & 24 & 8.3 & 12 \\
thompsoni & $12.0-15.9$ & 92.6 & 27 & 20.0 & 25 \\
& $16.0-18.5$ & 73.3 & 15 & 54.5 & 11 \\
& Total & 83.0 & 94 & 19.0 & 63 \\
Tarletonbeania & $4.6-7.9$ & 70.0 & 10 & 0.0 & 5 \\
taylori & $8.0-11.9$ & 88.6 & 35 & 5.6 & 18 \\
& $12.0-16.2$ & 84.4 & 32 & 0.0 & 22 \\
& Total & 84.4 & 77 & 2.2 & 45 \\
\hline
\end{tabular}

and upper jaw length were measured to the nearest 0.1 and $0.01 \mathrm{~mm}$, respectively. Notochord length (NL) was measured for preflexion larvae and standard length (SL) for flexion and postflexion larvae. Upper jaw length was measured from the tip of the snout to the posterior end of the maxilla, which was a good proxy for mouth diameter (Shirota 1970). In myctophid larvae, as upper jaw length varies more between species of a given size than mouth width (the width between the posterior edge of the maxillae in the ventral view), and seems to discriminate better among them (Sabatés \& Saiz 2000), we used only jaw length as a proxy of mouth size in our analyses. Hereafter, 'mouth size' refers to upper jaw length, unless otherwise specified.

Larval size (BL) ranged from 4.3 to $13.8 \mathrm{~mm}$ (mean \pm standard deviation: $8.6 \pm 2.5 \mathrm{~mm}$ ) in Diaphus theta, 4.3 to $18.5 \mathrm{~mm}(11.4 \pm 4.0 \mathrm{~mm})$ in Protomyctophum thompsoni, and 4.6 to $16.2 \mathrm{~mm}(11.3 \pm 2.8 \mathrm{~mm})$ in Tarletonbeania taylori (Fig. 2). Hatching length of the 3 species is $<3 \mathrm{~mm} \mathrm{NL}$, and the yolk is absorbed by the time they reach ca. $3.5 \mathrm{~mm}$ NL (Ozawa 1988, Moser \& Ahlstrom 1996). This suggests that first feeding occurs at a size of $>3.5 \mathrm{~mm}$ NL. The size range of transformation from larvae to juveniles is $11-14 \mathrm{~mm} \mathrm{SL}$ for $D$. theta, 17.2-18.8 mm SL for P. thompsoni, and 19.3-21.7 mm SL for T. taylori (Ozawa 1988, Moser \& Ahlstrom 1996). Our study covered almost all larval stages after yolksac absorption, except for first-feeding larvae of D. theta (3.5-4.3 mm NL), P. thompsoni (3.5-4.3 mm $\mathrm{NL}$ ), and T. taylori (3.5-4.6 mm NL), and for transforming and just before transforming larvae of $T$. taylori (16.2-21.7 $\mathrm{mm}$ SL). The gut of each larva was dissected from the body and opened lengthwise with fine needles. Prey items were counted and identified to the lowest possible taxon. The maximum body width of each prey item (hereafter referred to as prey width) that the larvae would have to encompass for ingestion was measured to the nearest $0.01 \mathrm{~mm}$ along the maximum cross section under a microscope fitted with an ocular micrometer (Blaxter 1963, Arthur 1976).

Data analysis. Gut contents of larvae from different localities and years were examined (Fig. 1). All larvae that had identifiable prey in their guts were used for the analysis. Feeding incidence was calculated as a percentage of the number of larvae that had gut contents out of the total number of larvae examined for the daytime and nighttime samples. Feeding incidence was considered a measure of feeding success or feeding rate in the field.

Prey items of the 3 species were evaluated using the percentage of each item out of the total number of diet items examined ( $\% \mathrm{~N})$ and percent frequency of occurrence of each prey item ( $\% \mathrm{~F}$ ) in all larvae that had gut contents. The product of $\% \mathrm{~N}$ and $\% \mathrm{~F}$ was used as an index of the relative importance (IRI) of each prey item.

We separated the larvae of the 3 species into 3 or 4 size classes to assess ontogenetic changes in feeding incidence and prey composition with growth at 3 and $4 \mathrm{~mm}$ intervals, i.e. $4.8-7.9 \mathrm{~mm}, 8-11.9 \mathrm{~mm}$, and 12-13.8 mm BL for Diaphus theta; 4.3-7.9 mm, 8-11.9 mm, 12-15.9 mm, and 16-18.5 mm BL for Protomyctophum thompsoni; and 4.6-7.9 mm, 8-11.9 $\mathrm{mm}$, and 12-16.2 mm BL for Tarletonbeania taylori. Notochord flexion takes place between 5.5 and $6.8 \mathrm{~mm}$ BL in D. theta, between 7.9 and $9.9 \mathrm{~mm} \mathrm{BL}$ in P. thompsoni, and between 7.8 and $10.5 \mathrm{~mm}$ BL in T. taylori (Moser \& Ahlstrom 1996). Thus, larvae in the smallest size classes of $<8 \mathrm{~mm}$ BL in $P$. thompsoni and T. taylori were at the preflexion stage, whereas $<8 \mathrm{~mm}$ BL larvae of $D$. theta included preflexion, flexion, and postflexion stages.

Intraspecific differences in prey size were examined throughout larval development. Pearre's trophic niche breadth (Pearre 1986) was adopted to analyze the relationship between prey size and predator size. This model adopts the standard deviation (SD) of the $\log _{10^{-}}$ transformed prey size as a measure of trophic niche breadth. In this analysis, fish larvae were classified according to body length at $0.1 \mathrm{~mm}$ intervals. Only classes with $>1$ prey item in the gut were used for further analyses. The average and SD of the $\log _{10^{-}}$ transformed prey width was calculated for each available size class of larval fishes. The relationship between body length and the corresponding average and SD of the $\log _{10}$-transformed prey size was examined using linear regression analysis to determine any shifts in niche breadth with growth.

Regression analysis was used to determine the relationship between number of prey in the gut and larval body length. The relationship between body length and 
upper jaw length was fitted using linear, allometric, and logarithmic formulae using the least squares method to adopt the best fitted formulae, as the relationships among larvae of different myctophids are quite different. For example, Myctophum asperum are fitted with a logarithmic formula and Diaphus garmani are fitted with an allometric formula (Sassa \& Kawaguchi 2004). The Shannon-Wiener diversity index $\left(H^{\prime}\right.$; Shannon \& Weaver 1949) was used as a measure of prey species diversity.

To discuss the possible competition for prey among the 3 myctophids and Engraulis japonicus larvae, we referred to the results of gut content analysis of E. japonicus larvae obtained by Funakoshi (1984), Uotani (1985), Mitani (1988), Uotani et al. (1988), and Hirakawa et al. (1997).

\section{RESULTS}

\section{Vertical distribution}

More than $90 \%$ of Diaphus theta larvae were distributed in the upper $50 \mathrm{~m}$, while Protomyctophum thompsoni and Tarletonbeania taylori larvae were mainly distributed at 50 to $150 \mathrm{~m}$ (Table 3 ). Thus, the habitat depth of $D$. theta was segregated from those of the other 2 species. As no apparent difference was recognized between the daytime and nighttime vertical distributions of the 3 species, we combined daytime and nighttime data.

\section{Feeding incidence}

The smallest larvae with gut contents were 4.5, 4.3, and $5.1 \mathrm{~mm}$ BL for Diaphus theta, Protomyctophum thompsoni, and Tarletonbeania taylori, respectively; thus, first-feeding larvae during the first few days of feeding were not represented in our samples. More than $60 \%$ (feeding incidence, 60.4 to $83.3 \%$ ) of $D$. theta larvae in all size classes caught during the day had food in their guts (Table 2), whereas larvae

Table 3. Diaphus theta, Protomyctophum thompsoni, and Tarletonbeania taylori. Vertical distribution of the larvae in the transition region of the western North Pacific. Mean abundance (larvae per $1000 \mathrm{~m}^{3}$ ) and standard deviation (SD) of each layer were shown. N: number of samples

\begin{tabular}{|c|c|c|c|c|c|c|c|}
\hline \multirow[t]{2}{*}{$\begin{array}{l}\text { Depth } \\
\text { (m) }\end{array}$} & \multirow[t]{2}{*}{$\mathrm{N}$} & \multicolumn{2}{|c|}{$\begin{array}{l}\text { Diaphus } \\
\text { theta }\end{array}$} & \multicolumn{2}{|c|}{$\begin{array}{l}\text { Protomyctophum } \\
\text { thompsoni }\end{array}$} & \multicolumn{2}{|c|}{$\begin{array}{c}\text { Tarletonbeania } \\
\text { taylori }\end{array}$} \\
\hline & & Mean & $\mathrm{SD}$ & Mean & $\mathrm{SD}$ & Mean & $\mathrm{SD}$ \\
\hline $0-25$ & 12 & 15.49 & 39.45 & 0.00 & 0.00 & 0.00 & 0.00 \\
\hline $25-50$ & 12 & 36.57 & 47.77 & 0.00 & 0.00 & 0.56 & 1.92 \\
\hline $50-150$ & 12 & 2.34 & 2.62 & 9.50 & 8.19 & 6.08 & 7.83 \\
\hline $150-250$ & 10 & 0.00 & 0.00 & 2.50 & 3.18 & 0.61 & 1.51 \\
\hline
\end{tabular}

ranging from 4.8 to $11.9 \mathrm{~mm}$ BL collected at night contained no food in their guts. In the largest size class (12-13.8 mm BL), however, $12.5 \%$ of larvae caught at night contained some prey items (Table 2). More than $70 \%$ (73.3 to $92.6 \%$ ) of $P$. thompsoni larvae in all size classes had food in their guts during the daytime (Table 2). They also showed some feeding incidence ( 0 to $54.5 \%$ ) at night, but this was significantly lower than the daytime values (mean: 19.0 vs. $83.0 \%$, respectively; Mann-Whitney $U$-test, $\mathrm{p}<0.05)$. The feeding incidence was $>70 \%$ (70.0 to $88.6 \%$ ) in all size classes of $T$. taylori during the daytime, while at night it decreased to $<6 \%$ (Table 2). These diel changes in feeding incidence indicate that these larvae are daytime, i.e. visual, feeders.

Daytime feeding incidence of the 3 species tended to gradually increase ontogenetically, probably as a result of increased catchability of prey (Table 2). Nighttime feeding incidence of Protomyctophum thompsoni also increased with development, from $0 \%$ at 4.3-7.9 $\mathrm{mm}$ BL to $54.5 \%$ in the largest size class (16-18.5 mm BL). A similar tendency was also observed in the nighttime feeding incidence of Diaphus theta, although nighttime feeding was restricted to the largest size class.

\section{Diet composition and trophic ontogeny}

The main food items detected in the guts of Diaphus theta, Protomyctophum thompsoni, and Tarletonbeania taylori are listed by size category in Tables 4, 5, \& 6 , respectively. Copepods at various developmental stages were the predominant prey of the 3 myctophids in terms of numbers.

Diaphus theta larvae of the smallest size class, 4.8-7.9 mm BL, fed mainly on copepod nauplii, which accounted for $72.7 \%$ of the total number of prey identified (Table 4). With growth, the importance of nauplii decreased and was replaced by calanoid copepodites and Oithona spp., which constituted 14.7 to $54.4 \%$ and 22.1 to $23.1 \%$, respectively, of the total number of prey examined (Table 4). Identification of calanoid copepodites to the genus level was not always possible, since most of them were at the early developmental stages and showed no diagnostic characteristics. In the largest size class (12-13.8 mm BL), Pseudo/ Paracalanus spp. $(23.5 \%)$ and $\mathrm{Neo}$ calanus spp. (11.8\%) dominated the calanoid copepodites (Table 4).

Protomyctophum thompsoni in the smallest size class, $4.3-7.9 \mathrm{~mm} \mathrm{BL}$, consumed mainly Oithona spp. 
Table 4. Prey composition of the 3 size classes of Diaphus theta larvae. Percent of the total number (\% N) of diet items and percent frequency of the occurrence ( $\%$ F) of a diet item among larvae with food in their guts were multiplied, and the product $(\% \mathrm{~N} \times \% \mathrm{~F})$ was taken as an index of relative importance (IRI). -: no occurrence

\begin{tabular}{|c|c|c|c|c|c|c|c|c|c|}
\hline \multirow[t]{2}{*}{ Food items } & \multicolumn{3}{|c|}{$48-79$} & \multicolumn{3}{|c|}{$\begin{array}{c}\text { Size range of larvae (mm BL) } \\
\quad 8.0-11.9\end{array}$} & \multirow{2}{*}{$\% \mathrm{~N}$} & $12.0-13$. & \multirow[b]{2}{*}{ IRI } \\
\hline & $\% \mathrm{~N}$ & $\% \mathrm{~F}$ & IRI & $\% \mathrm{~N}$ & $\% \mathrm{~F}$ & IRI & & $\% \mathrm{~F}$ & \\
\hline Diatom & 2.3 & 3.1 & 7.3 & 0.9 & 4.0 & 3.5 & - & - & - \\
\hline \multicolumn{10}{|l|}{ Copepoda } \\
\hline Egg & 4.7 & 15.6 & 73.2 & 2.3 & 4.0 & 9.4 & - & - & - \\
\hline Nauplius & 72.7 & 87.5 & 6357.4 & 48.0 & 82.0 & 3932.2 & 11.8 & 57.1 & 672.3 \\
\hline \multicolumn{10}{|l|}{ Calanoid copepodite } \\
\hline Eucalanus spp. & - & - & - & 0.3 & 2.0 & 0.6 & - & - & - \\
\hline Neocalanus spp. & - & - & - & - & - & - & 11.8 & 71.4 & 840.3 \\
\hline Pseudo/Paracalanus spp. & 0.8 & 3.1 & 2.4 & 1.2 & 8.0 & 9.4 & 23.5 & 85.7 & 2016.8 \\
\hline Unidentifiable calanoid & 1.6 & 3.1 & 4.9 & 13.2 & 26.0 & 342.1 & 19.1 & 85.7 & 1638.7 \\
\hline \multicolumn{10}{|l|}{ Cyclopoid copepodite } \\
\hline Oithona spp. & 3.9 & 12.5 & 48.8 & 23.1 & 54.0 & 1247.4 & 22.1 & 57.1 & 1260.5 \\
\hline Unidentifiable cyclopoid & - & - & - & 0.3 & 2.0 & 0.6 & - & - & - \\
\hline \multicolumn{10}{|l|}{ Poecilostomatoid copepodite } \\
\hline Oncaea spp. & - & - & - & 0.6 & 2.0 & 1.2 & - & - & - \\
\hline Unidentified copepoda & 2.3 & 9.4 & 22.0 & 3.2 & 18.0 & 57.9 & 5.9 & 28.6 & 168.1 \\
\hline \multicolumn{10}{|l|}{ Euphausiidae } \\
\hline Calyptopis & 0.8 & 3.1 & 2.4 & 1.8 & 4.0 & 7.0 & 1.5 & 14.3 & 21.0 \\
\hline Furcilia & - & - & - & - & - & - & 2.9 & 28.6 & 84.0 \\
\hline Appendicularians & 2.3 & 3.1 & 7.3 & 1.5 & 6.0 & 8.8 & 1.5 & 14.3 & 21.0 \\
\hline Unidentifiable material & 3.9 & 15.6 & 61.0 & 1.8 & 12.0 & 21.1 & - & - & - \\
\hline Unidentified crustacean & 4.7 & 15.6 & 73.2 & 0.9 & 4.0 & 3.5 & - & - & - \\
\hline Unidentified egg & - & - & - & 1.2 & 8.0 & 9.4 & - & - & - \\
\hline No. larvae examined & 68 & 82 & 22 & & & & & & \\
\hline No. empty stomachs & 36 & 32 & 15 & & & & & & \\
\hline Total no. prey items identified & 128 & 342 & 68 & & & & & & \\
\hline Diversity index $\left(H^{\prime}\right)$ & 1.18 & 1.61 & 1.89 & & & & & & \\
\hline
\end{tabular}

$(44.0 \%)$, copepod eggs $(22.6 \%)$, and copepod nauplii $(21.4 \%)$, which accounted for $88.0 \%$ of the total prey identified and decreased below $20 \%$ in the largest size class (16-18.5 mm BL; Table 5). Calanoid copepodites became more common and contributed 43.6 and $42.4 \%$ of the total prey identified in the larger size classes (12-15.9 and 16-18.5 mm BL, respectively). Although most of the calanoid copepodites were unidentifiable (32.1 to $32.8 \%$ ), mainly due to their advanced stages of digestion, Neocalanus spp. (4.4 to $9.0 \%$ ) and Pseudo/Paracalanus spp. (0 to $5.4 \%$ ) were thought to be the most important for these size classes. In addition, ostracods accounted for $24.4 \%$ and ranked second in the largest size class (Table 5).

In Tarletonbeania taylori, the smallest size class (4.6-7.9 mm BL) depended mainly on Oithona spp. $(40.2 \%)$ and copepod nauplii $(39.2 \%)$, but the importance of these groups decreased with larval growth; they made up 11.1 and $2.6 \%$, respectively, in the largest size class (12-16.2 $\mathrm{mm} \mathrm{BL;} \mathrm{Table} \mathrm{6).} \mathrm{In} \mathrm{the}$ 8-11.9 and 12-16.2 mm BL size classes, copepod eggs (mean diameter $\pm \mathrm{SD}: 150 \pm 26 \mu \mathrm{m}$ ) were the most abundant prey, accounting for 57.4 and $47.1 \%$ of the total prey, respectively. With growth, calanoid cope- podites and ostracods became more common in the largest size class, accounting for 16.9 and $8.5 \%$ of the total prey identified, respectively (Table 6). Pseudo/ Paracalanus spp. was the most abundant among identifiable calanoid copepodites, accounting for 3.1 to $4.2 \%$ (Table 6$)$. The diversity of prey items $\left(H^{\prime}\right)$ gradually increased with larval development in the 3 species examined (Tables 4 to 6).

\section{Prey size and trophic niche breadth}

Prey size ranges of Diaphus theta, Protomyctophum thompsoni, and Tarletonbeania taylori larvae were 35-480 $\mu \mathrm{m}, 60-1000 \mu \mathrm{m}$, and 60-1550 $\mu \mathrm{m}$, respectively, and these size ranges widened with larval development in all 3 species (Fig. 3), because the maximum prey size increased with growth. As the untransformed prey size data were highly scattered, especially for larger larvae (Fig. 3), we adopted the procedure of Pearre (1986) to compare the prey size shifts and niche breadths among the 3 species. Logarithmic average prey sizes linearly correlated with larval body length (Fig. 3, Table $7 ; \mathrm{r}^{2}=0.588$, df $=48, \mathrm{p}<0.001$ for 
Table 5. Prey composition of the 4 size classes of Protomyctophum thompsoni larvae. Percent of the total number (\% N) of diet items and percent frequency of the occurrence ( $\%$ F) of a diet item among larvae with food in their guts were multiplied, and the product ( $\% \mathrm{~N} \times \% \mathrm{~F}$ ) was taken as an index of relative importance (IRI). -: no occurrence

\begin{tabular}{|c|c|c|c|c|c|c|c|c|c|c|c|c|}
\hline \multirow{3}{*}{ Food items } & \multicolumn{9}{|c|}{ Size range of larvae (mm BL) } & \multirow{2}{*}{\multicolumn{3}{|c|}{$-16.0-18.5-$}} \\
\hline & \multirow{2}{*}{$\overline{\% \mathrm{~N}}$} & \multicolumn{2}{|c|}{$4.3-7.9$} & \multicolumn{3}{|c|}{$-8.0-11.9-$} & \multicolumn{3}{|c|}{$-12.0-15.9$} & & & \\
\hline & & $\% \mathrm{~F}$ & IRI & $\% \mathrm{~N}$ & $\% \mathrm{~F}$ & IRI & $\% \mathrm{~N}$ & $\% \mathrm{~F}$ & IRI & $\% \mathrm{~N}$ & $\% \mathrm{~F}$ & IRI \\
\hline Ostracoda & - & - & - & - & - & - & 4.4 & 6.7 & 29.4 & 24.4 & 47.1 & 1146.3 \\
\hline \multicolumn{13}{|l|}{ Copepoda } \\
\hline Egg & 22.6 & 23.8 & 538.5 & 6.0 & 18.2 & 109.5 & 12.7 & 13.3 & 169.9 & 5.1 & 17.6 & 90.5 \\
\hline Nauplius & 21.4 & 33.3 & 714.3 & 14.5 & 36.4 & 525.7 & 7.8 & 23.3 & 183.0 & 6.4 & 17.6 & 113.1 \\
\hline \multicolumn{13}{|l|}{ Calanoid copepodite } \\
\hline Calanus spp. & - & - & - & 2.4 & 9.1 & 21.9 & 0.5 & 3.3 & 1.6 & - & - & - \\
\hline Eucalanus spp. & - & - & - & - & - & - & 0.5 & 3.3 & 1.6 & 1.3 & 5.9 & 7.5 \\
\hline Neocalanus spp. & 1.2 & 4.8 & 5.7 & 2.4 & 9.1 & 21.9 & 4.4 & 20.0 & 88.2 & 9.0 & 17.6 & 158.4 \\
\hline Pseudo/Paracalanus spp. & - & - & - & 1.2 & 4.5 & 5.5 & 5.4 & 20.0 & 107.8 & - & - & - \\
\hline Unidentifiable calanoid & 7.1 & 28.6 & 204.1 & 15.7 & 45.5 & 711.9 & 32.8 & 76.7 & 2518.0 & 32.1 & 47.1 & 1508.3 \\
\hline \multicolumn{13}{|l|}{ Cyclopoid copepodite } \\
\hline Oithona spp. & 44.0 & 61.9 & 2726.8 & 34.9 & 27.3 & 952.9 & 8.3 & 46.7 & 388.9 & 7.7 & 23.5 & 181.0 \\
\hline \multicolumn{13}{|l|}{ Poecilostomatoid copepodite } \\
\hline Oncaea spp. & 1.2 & 4.8 & 5.7 & 2.4 & 9.1 & 21.9 & 1.0 & 6.7 & 6.5 & 1.3 & 5.9 & 7.5 \\
\hline Unidentified copepoda & 2.4 & 9.5 & 22.7 & 13.3 & 18.2 & 241.0 & 17.6 & 53.3 & 941.2 & 7.7 & 23.5 & 181.0 \\
\hline \multicolumn{13}{|l|}{ Euphausiidae } \\
\hline Egg & - & - & - & - & - & - & 1.0 & 6.7 & 6.5 & 1.3 & 5.9 & 7.5 \\
\hline Calyptopis & - & - & - & 6.0 & 18.2 & 109.5 & 1.5 & 6.7 & 9.8 & 3.8 & 11.8 & 45.2 \\
\hline Unidentifiable material & - & - & - & - & - & - & 1.5 & 10.0 & 14.7 & - & - & - \\
\hline Unidentified crustacean & - & - & - & - & - & - & 0.5 & 3.3 & 1.6 & - & - & - \\
\hline No. larvae examined & & 43 & & & 36 & & & 52 & & & 26 & \\
\hline No. empty stomachs & & 22 & & & 14 & & & 22 & & & 9 & \\
\hline Total no. prey items identified & & 84 & & & 83 & & & 204 & & & 78 & \\
\hline Diversity index $\left(H^{\prime}\right)$ & & 1.41 & & & 1.88 & & & 2.07 & & & 1.94 & \\
\hline
\end{tabular}

D. theta; $\mathrm{r}^{2}=0.446, \mathrm{df}=55, \mathrm{p}<0.001$ for $P$. thompsoni; $\mathrm{r}^{2}=0.253, \mathrm{df}=41, \mathrm{p}<0.001$ for $T$. taylori). The rate of prey size shift with growth (i.e. the slope of the line for the prey size/larval fish length relationship) was higher for D. theta (0.047) than for P. thompsoni (0.031) and T. taylori (0.036; Table 7). Niche breadths of $D$. theta and T. taylori were independent of their larval size and did not change during larval development (regression analysis for each species, $\mathrm{p}>0.1$, Table 7 ). The average niche breadths of these 2 species were $0.15 \pm 0.07$ (mean $\pm \mathrm{SD}$ ) and $0.15 \pm 0.10$, respectively (Fig. 3). In contrast, we observed a positive relationship between larval size and niche breadth in $P$. thompsoni (Table 7 ; $\mathrm{r}^{2}=0.284$, df $=55, \mathrm{p}<0.001$ ), with average niche breadths of $0.12 \pm 0.08$ at $<12 \mathrm{~mm} \mathrm{BL}$ and $0.19 \pm 0.10$ at $>12 \mathrm{~mm}$ BL (Fig. 3), showing an ontogenetic shift.

The increase in mouth size during larval growth differed among the 3 species (Fig. 4). The rate of increase was highest for Diaphus theta, and the predicted mouth sizes for this species increased linearly from $0.33 \mathrm{~mm}$ at $5 \mathrm{~mm}$ BL to $2.79 \mathrm{~mm}$ at $14 \mathrm{~mm} \mathrm{BL}$. The mouth sizes of Protomyctophum thompsoni and Tarletonbeania taylori were similar at $5 \mathrm{~mm} \mathrm{BL}$, i.e. 0.48 and $0.51 \mathrm{~mm}$, respectively (Fig. 4). However, the predicted mouth sizes for $P$. thompsoni at 10 and $15 \mathrm{~mm}$
BL were 1.18 and $1.98 \mathrm{~mm}$, respectively, while those for $T$. taylori were 1.34 and $2.37 \mathrm{~mm}$, and were larger than those of $P$. thompsoni with corresponding body sizes (Fig. 4). Prey size (maximum prey width) as a percentage of mouth size for $D$. theta, $P$. thompsoni, and T. taylori ranged from 1.6 to $42.9 \%$ (mean \pm SD: $9.3 \pm$ $4.8 \%), 2.3$ to $44.9 \%(12.0 \pm 6.8 \%)$, and 2.4 to $62.0 \%$ $(11.4 \pm 8.7 \%)$, respectively, showing the significantly lower value of $D$. theta, as compared to the other 2 species $\left(\mathrm{ANOVA} ; F_{2,959}=16.67, \mathrm{p}<0.001\right)$.

\section{Number of prey items per gut}

We examined only daytime samples, since larvae of the 3 species fed mostly during the daytime (Table 2). Numbers of prey items per gut ranged from 0 to 65,0 to 24, and 0 to 116 in Diaphus theta, Protomyctophum thompsoni, and Tarletonbeania taylori larvae, respectively. In D. theta and P. thompsoni, numbers of prey items in the gut were positively correlated to body length (Fig. 5; $\mathrm{r}^{2}=0.067, \mathrm{df}=122, \mathrm{p}<0.01$ for D. theta; $\mathrm{r}^{2}=0.073, \mathrm{df}=93, \mathrm{p}<0.01$ for $P$. thompsoni), suggesting an increase in feeding ability with growth. The average number of prey found per gut of D. theta 
Table 6. Prey composition of the 3 size classes of Tarletonbeania taylori larvae. Percent of the total number (\% N) of diet items and percent frequency of the occurrence ( $\%$ F) of a diet item among larvae with food in their guts were multiplied, and the product $(\% \mathrm{~N} \times \% \mathrm{~F})$ was taken as an index of relative importance (IRI). -: no occurrence

\begin{tabular}{|c|c|c|c|c|c|c|c|c|c|}
\hline \multirow[t]{3}{*}{ Food items } & \multirow{3}{*}{$\% \mathrm{~N}$} & \multirow{3}{*}{$\begin{array}{c}4.6-7.9 \\
\% F\end{array}$} & \multirow{3}{*}{$\overline{\text { IRI }}$} & \multirow{2}{*}{\multicolumn{3}{|c|}{ Size range of larvae $(\mathrm{mm} \mathrm{BL})$}} & \multirow{2}{*}{\multicolumn{3}{|c|}{$-12.0-16.2$}} \\
\hline & & & & & & & & & \\
\hline & & & & $\% \mathrm{~N}$ & $\% \mathrm{~F}$ & IRI & $\% \mathrm{~N}$ & $\% \mathrm{~F}$ & IRI \\
\hline Foraminifera & - & - & - & - & - & - & 0.3 & 3.7 & 1.2 \\
\hline Polychaete & 2.1 & 28.6 & 58.9 & 2.7 & 12.5 & 34.0 & 1.0 & 3.7 & 3.6 \\
\hline Ostracoda & - & - & - & 0.7 & 9.4 & 6.4 & 8.5 & 48.1 & 409.1 \\
\hline \multicolumn{10}{|l|}{ Copepoda } \\
\hline Egg & 9.3 & 42.9 & 397.6 & 57.4 & 53.1 & 3047.8 & 47.1 & 22.2 & 1045.8 \\
\hline Nauplius & 39.2 & 71.4 & 2798.2 & 8.6 & 40.6 & 350.1 & 2.6 & 18.5 & 48.4 \\
\hline \multicolumn{10}{|l|}{ Calanoid copepodite } \\
\hline Calanus spp. & - & - & - & - & - & - & 2.3 & 7.4 & 16.9 \\
\hline Candacia spp. & - & - & - & - & - & - & 0.3 & 3.7 & 1.2 \\
\hline Eucalanus spp. & - & - & - & - & - & - & 0.3 & 3.7 & 1.2 \\
\hline Neocalanus spp. & - & - & - & - & - & - & 1.6 & 14.8 & 24.2 \\
\hline Pseudo/Paracalanus spp. & 3.1 & 28.6 & 88.4 & 3.9 & 25.0 & 96.4 & 4.2 & 18.5 & 78.7 \\
\hline Unidentifiable calanoid & 4.1 & 42.9 & 176.7 & 8.8 & 43.8 & 386.9 & 8.2 & 37.0 & 302.6 \\
\hline \multicolumn{10}{|l|}{ Cyclopoid copepodite } \\
\hline Oithona spp. & 40.2 & 71.4 & 2871.9 & 11.1 & 43.8 & 486.1 & 11.1 & 25.9 & 288.1 \\
\hline \multicolumn{10}{|l|}{ Poecilostomatoid copepodite } \\
\hline Oncaea spp. & - & - & - & 0.9 & 9.4 & 8.5 & 1.3 & 14.8 & 19.4 \\
\hline Unidentified copepoda & - & - & - & 3.4 & 25.0 & 85.0 & 5.2 & 25.9 & 135.6 \\
\hline Amphipoda & - & - & - & - & - & - & 0.3 & 3.7 & 1.2 \\
\hline \multicolumn{10}{|l|}{ Euphausiidae } \\
\hline Egg & - & - & - & - & - & - & 0.3 & 3.7 & 1.2 \\
\hline Calyptopis & 2.1 & 28.6 & 58.9 & 0.5 & 6.3 & 2.8 & 2.0 & 18.5 & 36.3 \\
\hline Furcilia & - & - & - & 0.2 & 3.1 & 0.7 & 0.3 & 3.7 & 1.2 \\
\hline Juvenile & - & - & - & 0.2 & 3.1 & 0.7 & - & - & - \\
\hline Heteropoda & - & - & - & 0.2 & 3.1 & 0.7 & - & - & - \\
\hline Appendicularians house & - & - & - & 0.2 & 3.1 & 0.7 & 1.3 & 7.4 & 9.7 \\
\hline Unidentifiable material & - & - & - & 0.9 & 12.5 & 11.3 & 1.0 & 11.1 & 10.9 \\
\hline Unidentified crustacean & - & - & - & - & - & - & 0.3 & 3.7 & 1.2 \\
\hline Unidentified egg & - & - & - & 0.2 & 3.1 & 0.7 & - & - & - \\
\hline No. larvae examined & 15 & 53 & 54 & & & & & & \\
\hline No. empty stomachs & 8 & 21 & 27 & & & & & & \\
\hline Total no. prey items identified & 97 & 441 & 306 & & & & & & \\
\hline Diversity index $\left(H^{\prime}\right)$ & 1.35 & 1.54 & 1.97 & & & & & & \\
\hline
\end{tabular}

increased from 3.0 in the $4-10 \mathrm{~mm}$ BL size class to 9.4 in the 10-14 mm BL class. In P. thompsoni, average prey number per gut increased from 3.2 in the 4-12 mm BL class to 6.1 in 12-18 mm BL larvae. T. taylori showed no positive correlation between number of prey and body length (Fig. $5 ; r^{2}=0.002$, df $=79$, p > 0.1 , owing to the large fluctuation in the number of copepod eggs per gut (Table 6). The average number of prey eaten by $T$. taylori was 9.3 individuals per gut throughout larval development (Fig. 5).

\section{Interspecific comparison of feeding habitats of six larval myctophids}

Using the present data for 3 species, together with previous data for Diaphus garmani and Myctophum asperum (Sassa \& Kawaguchi 2004), and for Symbolophorus californiensis (Sassa 2001), we made interspecific comparisons of feeding habits in relation to the relative mouth size (mouth size/body length ratio; Fig. 6). The rate of prey size shift with larval growth was positively related to the relative mouth size (Fig. 6a). The prey size, i.e. the average of the $\log _{10}$-transformed prey sizes at $0.1 \mathrm{~mm}$ larval size intervals in Fig. 3, also appeared to be positively related to the relative mouth size (Fig. 6b). On the other hand, average numbers of prey observed in the gut tended to be inversely related to the relative mouth size (Fig. 6c), indicating a prey size shift, i.e. larvae took a smaller number of larger prey instead of a larger number of smaller prey. This suggests that species with larger mouths tend to show larger prey size shifts, resulting in a smaller number of prey observed in the guts of the large-mouthed larvae. Niche breadth did not differ notably among species and was not related to relative mouth size (Fig. 6d). 

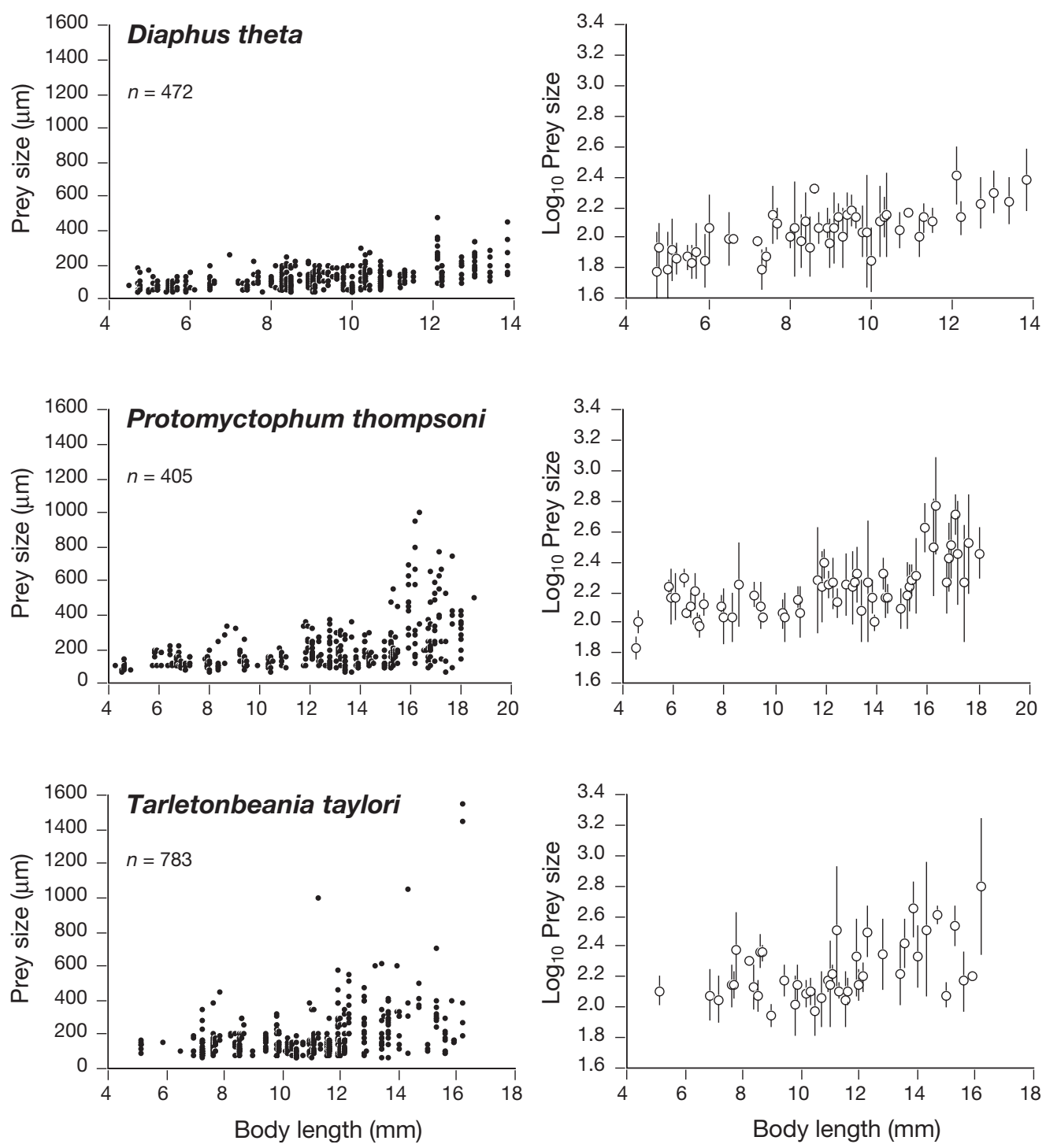

Fig. 3. Diaphus theta, Protomyctophum thompsoni, and Tarletonbeania taylori. Prey size-fish body length relationship for the 3 species. Prey size was measured as the maximum body width. Prey size in the figures on the left is untransformed raw data, while it is $\log _{10}$-transformed in those on the right

Table 7 . Weighted linear-regression analysis of average $\left(\log _{10}\right.$-transformed) prey width and trophic niche-breadth (SD of $\log _{10}$-transformed prey width) as a function of larval body length. Slope, intercept, corresponding standard errors (SE), and determination coefficients are shown. ${ }^{*} \mathrm{p}<0.01,{ }^{* *} \mathrm{p}<0.001$

\begin{tabular}{|c|c|c|c|c|c|}
\hline & Intercept & SE & Slope & SE & $\mathrm{r}^{2}$ \\
\hline \multicolumn{6}{|c|}{ Average prey width vs. larval body length } \\
\hline Diaphus theta & $1.631^{* *}$ & 0.053 & $0.047^{* *}$ & 0.006 & 0.588 \\
\hline Protomyctophum thompsoni & $1.855^{* *}$ & 0.059 & $0.031^{* *}$ & 0.005 & 0.446 \\
\hline Tarletonbeania taylori & $1.839^{* *}$ & 0.112 & $0.036^{*}$ & 0.010 & 0.253 \\
\hline \multicolumn{6}{|c|}{ Trophic niche-breadth vs. larval body length } \\
\hline Diaphus theta & $0.161^{*}$ & 0.041 & -0.001 & 0.004 & 0.001 \\
\hline Protomyctophum thompsoni & 0.007 & 0.034 & $0.013^{* *}$ & 0.003 & 0.284 \\
\hline Tarletonbeania taylori & 0.039 & 0.064 & 0.010 & 0.006 & 0.077 \\
\hline
\end{tabular}

\section{DISCUSSION}

\section{Feeding incidence and diurnal feeding}

Diaphus theta, Protomyctophum thompsoni, and Tarletonbeania taylori larvae fed mainly during the daytime in the epipelagic layer, suggesting that they are visual feeders. Larvae of other myctophid species, such as Benthosema glaciale, Ceratoscopelus maderensis, Hygophum benoiti, Lampanyctus crocodilus, Myctophum punctatum (Sabatés \& Saiz 2000), D. garmani, and M. asperum (Sassa \& 


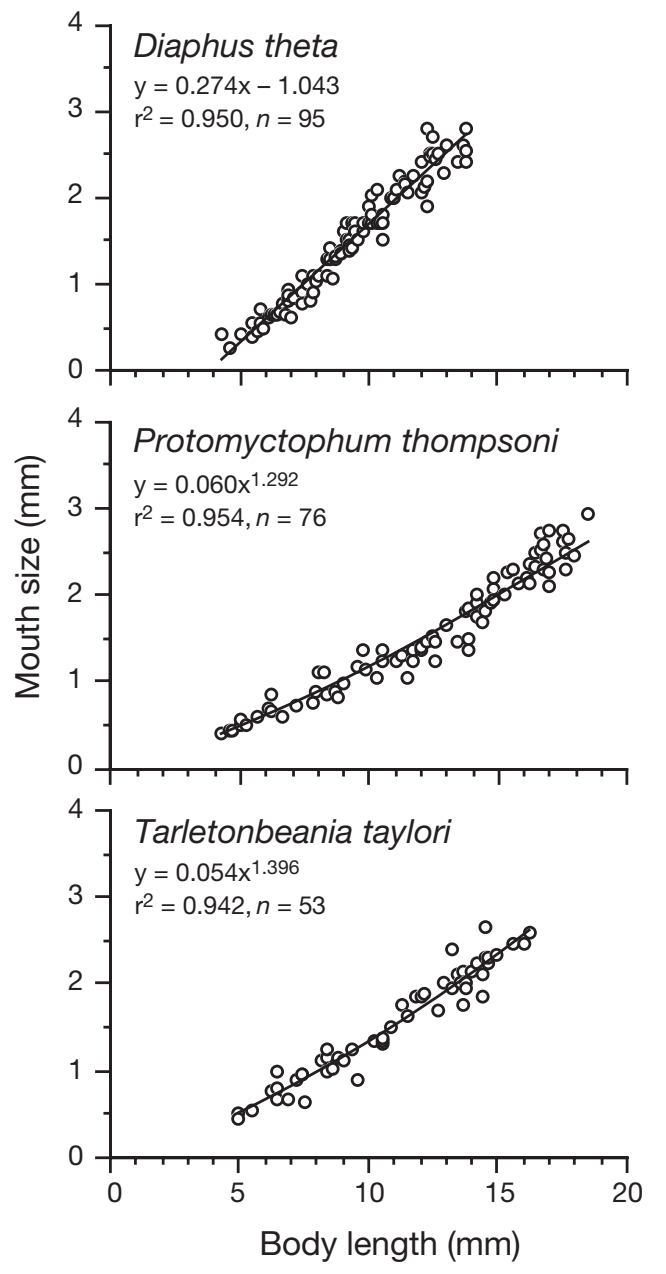

Fig. 4. Diaphus theta, Protomyctophum thompsoni, and Tarletonbeania taylori. Relationship between larval body length and mouth size

Kawaguchi 2004), also feed mainly during the daytime. The daytime feeding incidence of $D$. theta, P. thompsoni, and $T$. taylori increased gradually with development, as has been observed for D. garmani and $M$. asperum (Sassa \& Kawaguchi 2004). This is related to an enhanced searching ability with growth, since swimming speed, capture success rates, and perceptive distances are functions of body length or age (Hunter 1981).

Incidences of nighttime feeding among Protomyctophum thompsoni larvae apparently increased with development, from $0 \%$ at $4.3-7.9 \mathrm{~mm} \mathrm{BL}$ to $54.5 \%$ at $16-18.5 \mathrm{~mm} \mathrm{BL}$, showing that the larvae begin feeding at night after they reach a certain size. This would suggest faster larval adaptation to mesopelagic life under poor light conditions, as P. thompsoni is non-migrant after transforming to the juvenile stage, and adults remain in the mesopelagic layer all day. The relatively high nighttime feeding incidence of $12.5 \%$ in the
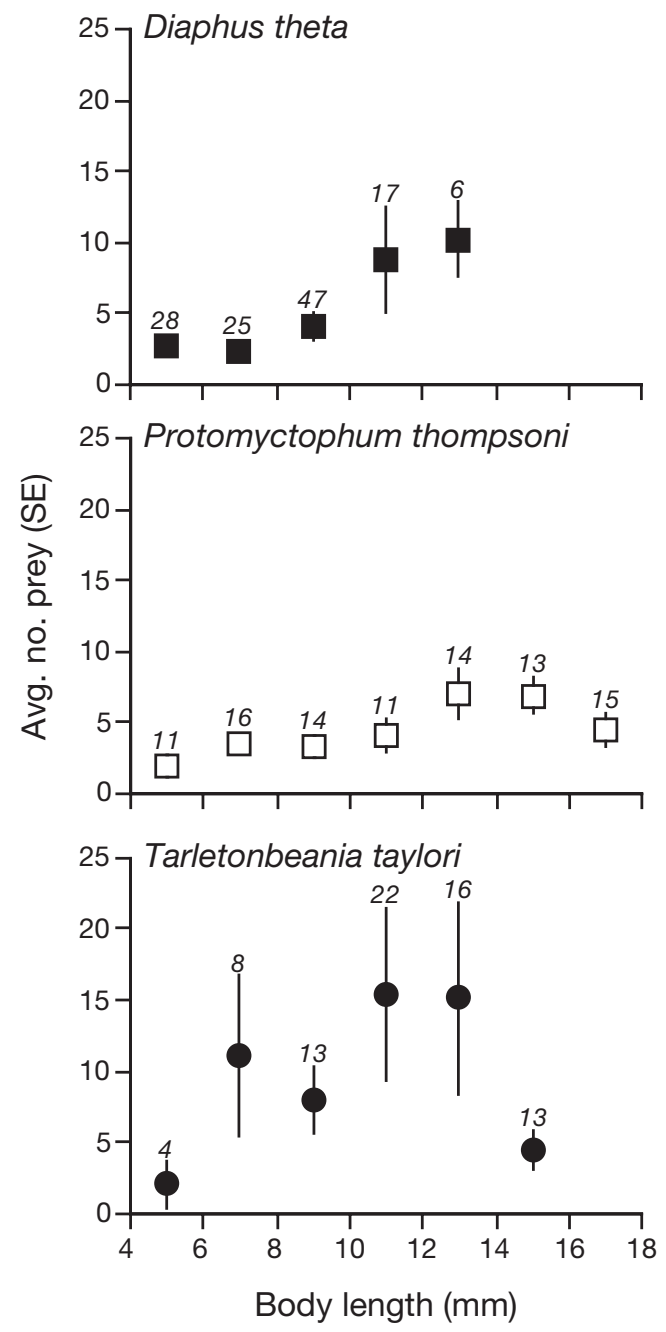

Fig. 5. Diaphus theta, Protomyctophum thompsoni, and Tarletonbeania taylori. Number of prey per gut in relation to body length $(\mathrm{mm})$. Numbers above the bars are the numbers of larvae examined

largest size class of Diaphus theta larvae may also indicate the onset of nocturnal feeding just before the juvenile stage. Similar ontogenetic changes in diel feeding have been also observed in Myctophum asperum larvae (Sassa \& Kawaguchi 2004).

Diaphus theta and Tarletonbeania taylori begin diel vertical migration and actively feed in the epipelagic layer at night after transformation from larvae to juveniles (Pearcy et al. 1977, Watanabe et al. 1999, Moku et al. 2000). In the highly productive subarctic and transition regions, adult $D$. theta feed actively, both during the daytime in the mesopelagic and at night in the epipelagic zones (Paxton 1967, Moku et al. 2000). Thus, after transformation to juveniles, $D$. theta change their feeding periodicity from diurnal to all-day feeding, while T. taylori shift their feeding from diurnal to nocturnal after transformation to juveniles. Proto- 
Fig. 6. Diaphus theta, Protomyctophum thompsoni, Tarletonbeania taylori, D. garmani, Myctophum asperum, and Symbolophorus californiensis. Relationship between mouth size:body length ratio (\%) and (a) rate of prey size shift (slope of $\log _{10}$ prey size/body length regression), (b) $\log _{10^{-}}$ transformed prey size, (c) number of prey in guts, and (d) niche breadth (mean SD of $\log _{10}$ prey for each body length class) of 6 myctophid fish species (indicated by combining the first letter of the genus name with the first 3 letters of the specific epithet). Error bars on the $y$-axis indicate SE for (a) and SD for (b to d). Mouth size as a percent of body length was estimated from mouth size:body length regression lines in Fig. 4. Data are means and ranges. *After Sassa (2001), **after Sassa \& Kawaguchi (2004)
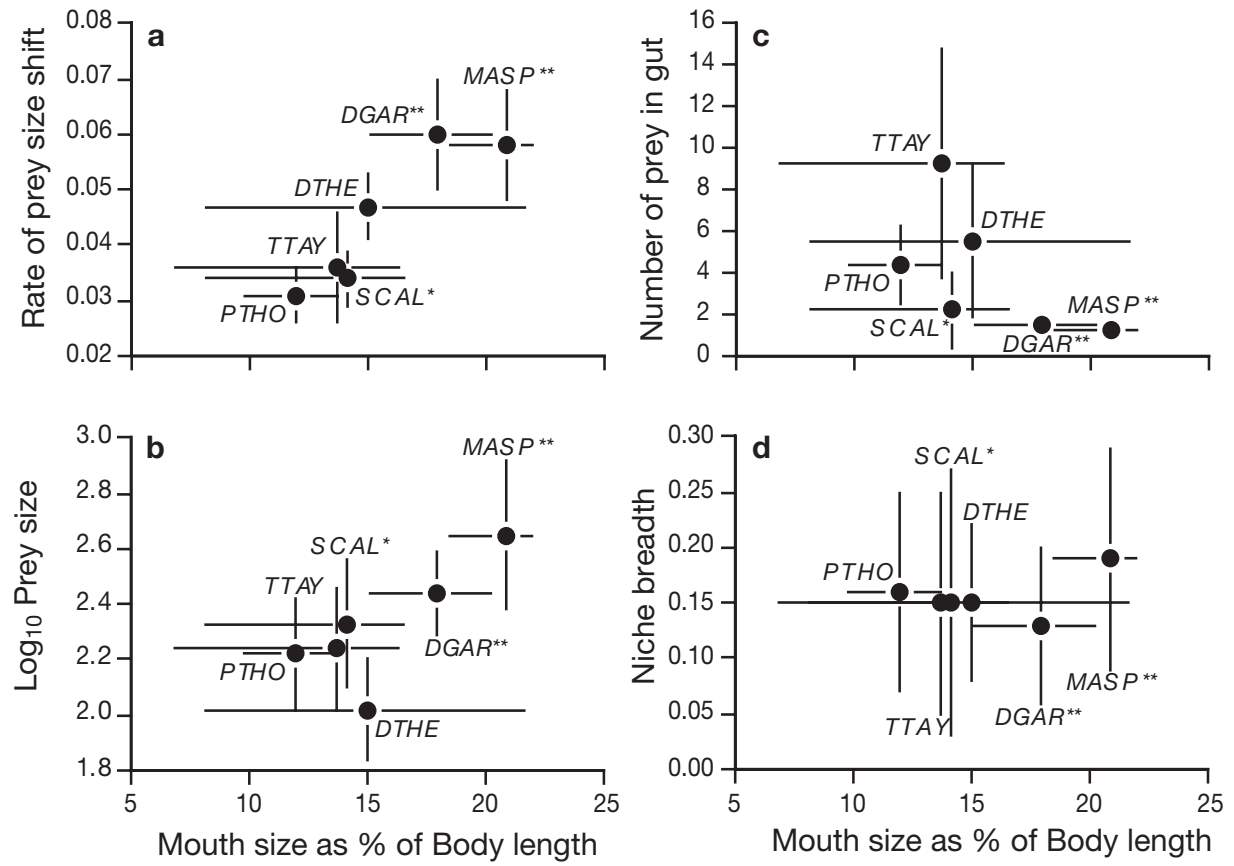

myctophum thompsoni is a non-migrant species that begins to stay in the 200 to 400 m layer from the juvenile stage (Pearcy et al. 1977, Watanabe et al. 1999). Adult $P$. thompsoni feed both during the day and at night in the mesopelagic zone. However, their feeding activity is more active during the daytime (Huruhashi 1987), as vertically migrating zooplankton prey are highly concentrated in the mesopelagic layer during the day. Our results, together with the report by Huruhashi (1987), suggest that $P$. thompsoni show no clear ontogenetic changes in diel feeding periodicity from larger larval stages ( $\geq 12 \mathrm{~mm} \mathrm{SL})$, through juvenile to adult stages; they are consistently day- and nighttime feeders, although feeding is more active during the day than at night.

\section{Diet composition and trophic ontogeny}

In the transition region of the western North Pacific, larvae of Diaphus theta, Protomyctophum thompsoni, and Tarletonbeania taylori depend mainly on copepods at various developmental stages including eggs, nauplii, copepodites, and adults. Sabatés \& Saiz (2000) examined the feeding habits of 5 coexisting myctophid larvae (Benthosema glaciale, Ceratoscopelus maderensis, Hygophum benoiti, Lampanyctus crocodilus, and Myctophum punctatum) in the western Mediterranean and found that $88 \%$ of the identified prey were copepod nauplii and copepodites. In general, copepods are thought to be the most important prey for myctophid larvae, although some notable exceptions exist in subtropical-tropical species. For example,
D. garmani depends mainly on appendicularian houses, while $M$. asperum feeds primarily on ostracods and polychaetes during its larval stages (Sassa \& Kawaguchi 2004).

We could not analyze feeding habits of the firstfeeding larvae for the 3 myctophid species due to lack of samples. Sabatés \& Saiz (2000) analyzed the gut content of preflexion larvae of 4 myctophid species including first-feeding stage $(<3 \mathrm{~mm} \mathrm{BL})$, and recognized no difference between these and older preflexion larvae, suggesting that the 3 species examined in this study would also show the similar feeding patterns with no remarkable change in prey composition from the first-feeding throughout the preflexion stage.

In our study, the smallest size class larvae $(<8 \mathrm{~mm}$ BL) of Protomyctophum thompsoni and Tarletonbeania taylori were at the preflexion stage, whereas $<8 \mathrm{~mm}$ BL Diaphus theta larvae included preflexion $(4.8-5.4 \mathrm{~mm})$, flexion $(5.5-6.7 \mathrm{~mm})$, and postflexion $(6.8-7.9 \mathrm{~mm})$ stages. D. theta larvae of these 3 developmental stages fed mainly on copepod nauplii, which accounted for $80.0,88.2$, and $66.7 \%$ of the total number of prey identified, respectively. Prey size range showed no significant difference among the 3 stages (Fig. 3). These results indicate that $D$. theta larvae show no remarkable change in prey and prey size from preflexion through to postflexion stages.

We examined the gut contents of Diaphus theta collected during May to June and September to October, but no significant seasonal difference was observed in the diet composition between early summer and autumn. In Protomyctophum thompsoni and Tarletonbeania taylori, it was difficult to compare the diet com- 
position between the 2 seasons, because daytime collection of the 2 species was limited in May to June; thus, our results for these 2 species represent the larval feeding habits in autumn.

For larvae of Diaphus theta, Protomyctophum thompsoni, and Tarletonbeania taylori, cyclopoid copepodites of Oithona spp. were among the most important prey during the early developmental stages. Oithona spp. are small copepods, commonly distributed at high densities in the epipelagic layer of the study area, both during the day and at night (Nishida \& Marumo 1982). The body width of Oithona spp. ranges from 150 to $400 \mu \mathrm{m}$ even at the adult stage, and many marine fish larvae feed on them (e.g. Arthur 1976, Uotani 1985, Mitani 1988). With increased growth, the importance of calanoid copepodites, such as Pseudo/ Paracalanus spp., increased for the 3 species investigated in this study. Both Paracalanus spp. and Pseudocalanus spp. are numerically the most dominant small-sized copepods and are widely distributed in the epipelagic layer of the transition region (Hattori 1991, Odate 1994). The zooplankton biomass shows a peak from spring to summer, with medium biomass maintained in autumn and low biomass in winter in the transition region (Odate 1994). This spring-summer peak in zooplankton corresponds to the seasonal peak abundance of the 3 myctophid species studied here (Sassa 2001, Moku et al. 2003, Sassa et al. 2004b).

Copepod eggs ca. $150 \mu \mathrm{m}$ in diameter were the most abundant diet item in the guts of Tarletonbeania taylori larvae $\geq 8.0 \mathrm{~mm} \mathrm{BL}$, resulting in a very high IRI value. Many individuals had only copepod eggs in their guts. Two possible reasons could explain the occurrence of copepod eggs: (1) eggs were released from adult female copepods that were consumed and (2) eggs were present as a result of selective feeding. Pseudocalanus spp. and Oithona spp. are egg-carrying copepods. In our study, no adult female Pseudocalanus spp. were found in the guts of T. taylori larvae; only copepodites in earlier developmental stages were recorded. Larvae of $T$. taylori sometimes consumed adult Oithona spp. with egg sacs, but their egg diameter was ca. 50 to $70 \mu \mathrm{m}$, i.e. substantially smaller than those found in the guts of T. taylori. In this study, we did not count Oithona spp. eggs because they were apparently released from consumed females and were considered negligible. It was easy to distinguish the much smaller Oithona spp. eggs from the $150 \mu \mathrm{m}$ eggs of copepods. Considering these findings, it is more plausible that the larvae fed selectively on large eggs originating from free-spawning copepods such as Calanus pacificus, which dominate the study area and spawn eggs 150 to $160 \mu \mathrm{m}$ in diameter (Mauchline 1998, Kobari et al. 2004).
Gorelova \& Efremenko (1989) also reported that crustacean eggs were frequently found in the guts of larval myctophids (Krefftichthys anderssoni and Electrona antarctica) in the Scotia Sea. Several species of clupeiform larvae also depend primarily on copepod eggs during their early development (Arthur 1976). However, the nutritional value of copepod eggs is low for early larvae (Hunter 1977, Tanaka 1980), as the eggshells are too hard for them to digest. It is likely that Tarletonbeania taylori larvae begin feeding on copepod eggs after their digestive systems have completely developed. A similar pattern of trophic ontogeny has been observed in the larvae of Atlantic croaker (Micropogonias undulatus; Govoni et al. 1983); small larvae eat copepodites and larger ones eat invertebrate eggs.

\section{Resource partitioning}

Myctophid larvae show species-specific larval distribution depths in the productive epipelagic zone of the upper 200 m layer, and show no diel vertical migration (Ahlstrom 1959, Loeb 1979a,b, Moser \& Smith 1993, Sassa et al. 2002b, 2004c). Larvae of both Protomyctophum thompsoni and Tarletonbeania taylori showed peak abundance in the 50 to $150 \mathrm{~m}$ layer in the study area (Table 8), suggesting potential competition for food between these species. Larvae of both species $\leq 7.9 \mathrm{~mm}$ BL mainly ate copepod nauplii and Oithona spp. ranging from 50 to 150 and 50 to $200 \mu \mathrm{m}$ in body width, respectively (Table 8), suggesting diet overlap. However, when they reached the notochord flexion stage at $8.0 \mathrm{~mm} \mathrm{BL}, P$. thompsoni depended more on calanoid copepodites and ostracods as well as copepod nauplii and Oithona spp., while T. taylori began to feed mainly on copepod eggs. Although T. taylori also consumed Oithona spp., calanoid copepodites, and ostracods, their IRI values were as low as $<500$. This finding suggests that resource partitioning between these 2 species starts after reaching $\geq 8.0 \mathrm{~mm}$ BL (Table 8). Larvae of these 2 species of $\leq 7.9 \mathrm{~mm}$ BL may occupy different habitat depths to avoid competition; however, our discrete vertical samples covered a depth of $100 \mathrm{~m}$ within the 50 to $150 \mathrm{~m}$ layer and were therefore too coarse to detect more detailed habitat segregation. Discrete sampling at a finer scale is necessary to examine differences in their habitat depths.

The distribution of Diaphus theta larvae is centered in the upper $50 \mathrm{~m}$ layer (Table 8, Sassa 2001) and is segregated from Protomyctophum thompsoni and Tarletonbeania taylori, suggesting no competition for prey (Table 8). A recent study indicated that D. garmani and Myctophum asperum larvae are also segregated, both in terms of diet and habitat in the study 
Table 8. Diaphus theta, Protomyctophum thompsoni, Tarletonbeania taylori, and Engraulis japonicus. Summary of vertical distribution and feeding habits of larvae in the transition region of the western North Pacific. The main prey of myctophid larvae were defined as items having an IRI $>500$. The width ranges of copepods that were primarily consumed are also shown. Larval habitat depths are based on Sassa (2001) and Tsukamoto et al. (2001). The main prey of E. japonicus larvae are after Funakoshi (1984), Uotani (1985), Mitani (1988), Uotani et al. (1988), and Hirakawa et al. (1997)

\begin{tabular}{|c|c|c|}
\hline Species & Habitat depth (m) & Main prey \\
\hline \multicolumn{3}{|l|}{ Diaphus theta } \\
\hline$\leq 7.9 \mathrm{~mm} \mathrm{BL}$ & $0-50$ & Copepod nauplii ${ }^{\mathrm{a}}$ \\
\hline$\geq 8.0 \mathrm{~mm} \mathrm{BL}$ & $0-50$ & Copepod nauplii ${ }^{\mathrm{a}}$, Oithona spp. ${ }^{\mathrm{b}}$, calanoid copepodites $^{\mathrm{c}}$ \\
\hline \multicolumn{3}{|c|}{ Protomyctophum thompsoni } \\
\hline$\leq 7.9 \mathrm{~mm} \mathrm{BL}$ & $50-150$ & Copepod eggs ${ }^{\mathrm{d}}{ }$ copepod nauplii $^{\mathrm{a}}$, Oithona spp. ${ }^{\mathrm{b}}$ \\
\hline$\geq 8.0 \mathrm{~mm} \mathrm{BL}$ & $50-150$ & Copepod nauplii ${ }^{\mathrm{a}}$, Oithona spp. ${ }^{\mathrm{b}}$, calanoid copepodites ${ }^{\mathrm{e}}$, ostracods \\
\hline \multicolumn{3}{|c|}{ Tarletonbeania taylori } \\
\hline$\leq 7.9 \mathrm{~mm} \mathrm{BL}$ & $50-150$ & Copepod nauplii ${ }^{\mathrm{a}}$, Oithona spp. ${ }^{\mathrm{b}}$ \\
\hline$\geq 8.0 \mathrm{~mm} \mathrm{BL}$ & $50-150$ & Copepod eggs ${ }^{\mathrm{d}}$ \\
\hline \multicolumn{3}{|c|}{ Engraulis japonicus } \\
\hline$\leq 7.9 \mathrm{~mm} \mathrm{BL}$ & $0-30$ & Copepod nauplii ${ }^{\mathrm{a}}$ \\
\hline$\geq 8.0 \mathrm{~mm} \mathrm{BL}$ & $0-30$ & Oithona spp. ${ }^{\mathrm{f}}$, calanoid copepodites ${ }^{\mathrm{g}}$ \\
\hline
\end{tabular}

area (Sassa \& Kawaguchi 2004). Juvenile and adult myctophids in the Gulf of Mexico and the Kuroshio region of the western North Pacific are also known to reduce competition through partitioning of habitat depth and zooplankton food resources (Hopkins \& Gartner 1992, Watanabe et al. 2002). To analyze the resource partitioning of myctophid larvae quantitatively, we need (1) to conduct sampling in a small area over a short timescale in order to reduce the effects of physical and oceanographic changes that are not related to larval behavior, (2) to conduct discrete vertical sampling at a finer scale, and (3) to assess prey abundance, prey productivity, and their distribution patterns in the field.

\section{Intraspecific changes in niche breadth}

The niche breadth of Diaphus theta and Tarletonbeania taylori larvae did not increase with growth, which agrees with the larval feeding patterns previously reported for 7 other myctophid species (Sabatés \& Saiz 2000, Sassa \& Kawaguchi 2004). However, that of Protomyctophum thompsoni increased ontogenetically, suggesting that constancy of niche breadth is not always universal among all myctophid larvae. Protomyctophum thompsoni is a small species that does not exceed $50 \mathrm{~mm} \mathrm{SL}$, and is thought to mature after $1 \mathrm{yr}$ and die after breeding. A similar pattern has been reported for $P$. arcticum, a sibling species of $P$. thompsoni in the subarctic Atlantic (Kawaguchi \& Mauchline 1982). The niche breadth increase during larval development of $P$. thompsoni may be related to this earlier maturity, since this type of life history strategy requires a rapid accumulation of nutrients for spawning from the early stages.

\section{Interspecific comparison of feeding strategies related to mouth size}

The value of Pearre's trophic niche breadth was approximately 0.15 for 6 myctophid species in the western North Pacific, and was not related to relative mouth size (Fig. 6d), corresponding to the results of Sabatés \& Saiz (2000) in the Mediterranean. The rate of prey size shift with larval growth was positively related to the relative mouth size (Fig. 6a), suggesting that larger-mouthed larvae could shift to larger prey. The prey of larger-mouthed larvae, such as Diaphus garmani and Myctophum asperum, were larger than those of the smaller-mouthed larvae we examined (Fig. 6b). Conversely, the average number of prey consumed by the small-mouthed larvae was higher than that of the larger-mouthed larvae (Fig. 6c), indicating that the smaller-mouthed larvae must consume more small prey to meet their metabolic requirements. This kind of interspecific mouth-prey size relationship was also suggested for the larval fish assemblage in Wakasa Bay in the western Sea of Japan (Ikewaki \& Sawada 1991); these authors analyzed 7 species belonging to 5 families (Scorpaenidae, Carangidae, Sparidae, Sillaginidae, and Trichiuridae). We found similar types of strategy among myctophid larvae; this variety of feeding strategy among myctophid larvae is reflected in their wide morphological diversity (Moser 
1981, Moser \& Ahlstrom 1996), and contributes, in all likelihood, to promoting the great variety of species in this family.

\section{Possible prey competition among fish larvae in the transition region}

During the late 1990s, the coastal waters off Japan supported a large population of the Japanese anchovy, Engraulis japonicus. The larval distribution of this species extended from coastal to offshore waters in the transition region, and the larvae formed one of the main components of the ichthyoplankton (Kubota et al. 2001, Takahashi et al. 2001). Recently, Sassa \& Kawaguchi (2004) suggested that the absence of competition for prey between E. japonicus and coexisting Diaphus garmani larvae in the transition region was the result of their diet segregation. D. theta larvae, however, potentially compete with $E$. japonicus for prey in the transition regions, as they have spatiotemporally similar habitats (Sassa 2001, Tsukamoto et al. 2001) and are 2 dominant species in the larval fish assemblage in the study area during early summer to autumn (Moku 2000, Sassa 2001). The distribution of E. japonicus larvae is centered in the upper $30 \mathrm{~m}$ layer during the day (Table 8, Ida 1972, Sassa 2001, Tsukamoto et al. 2001), and overlaps that of $D$. theta larvae. E. japonicus larvae of $\leq 7.9 \mathrm{~mm}$ BL feed mainly on copepod nauplii; the $\geq 8.0 \mathrm{~mm}$ BL larvae shift to the copepodite stages of Oithona spp. and Paracalanus spp. (Table 8, Funakoshi 1984, Uotani 1985, Mitani 1988, Uotani et al. 1988, Hirakawa et al. 1997). In this study, the prey of $D$. theta and E. japonicus larvae overlapped with each other throughout their development (Table 8).

The impact of larval myctophids on prey resources of other fish larvae is important in evaluating the carrying capacity for fish larvae of commercially important species in the transition region. However, knowledge of their feeding ecology is quite limited. Moreover, little is known about the production of their prey, especially small-sized copepods, in the study area. In the future, knowledge of (1) the abundance of myctophid larvae, (2) daily rations of these larvae, (3) daily production of their prey, and (4) prey densities in the field is required to quantitatively estimate the impact of myctophid larvae on marine prey resources.

Acknowledgements. We are grateful to the captains, officers, and crews of the RV 'Hakuho-Maru', 'Wakataka-Maru', and 'Soyo-Maru' for their assistance in the field. Drs. Y. Oozeki and H. Kubota of the National Research Institute of Fisheries Science, and Drs. H. Sugisaki and K. Taki of the Tohoku National Fisheries Research Institute kindly provided larval myctophid samples for gut content analysis. We thank the anonymous reviewers for their valuable comments on an earlier draft, and Prof. S. Nishida of the Ocean Research Institute, University of Tokyo, Dr. A. Yamaguchi of the Hokkaido University, and Dr. M. Moku of the Tohoku National Fisheries Research Institute for valuable discussions during the course of this study.

\section{LITERATURE CITED}

Ahlstrom EH (1959) Vertical distribution of pelagic fish eggs and larvae off California and Baja California. Fish Bull US 60:107-146

Ahlstrom EH (1969) Mesopelagic and bathypelagic fishes in the California current region. Calif Coop Ocean Fish Invest Rep 13:39-44

Arthur DK (1976) Food and feeding of larvae of three fishes occurring in the California current, Sardinops sagax, Engraulis mordax, and Trachurus symmetricus. Fish Bull US 74:517-530

Beamish RJ, Leask KD, Ivanov OA, Balanov AA, Orlov AM, Sinclair B (1999) The ecology, distribution, and abundance of midwater fishes of the Subarctic Pacific gyres. Prog Oceanogr 43:399-442

Bekker VE (1967) Luminescent anchovies: family Myctophidae. In: Rass TS (ed) Biology of the Pacific Ocean, Vol 7, Book III. Ratisu, Tokyo, p 145-181 (in Japanese, translated from Russian)

Blaxter JHS (1963) The feeding of herring larvae and their ecology in relation to feeding. Calif Coop Ocean Fish Invest Rep 10:79-88

Funakoshi S (1984) Food and survival of the early postlarvae of the Japanese anchovy, Engraulis japonica (HOUTTUYN). II. Distribution of anchovy larvae as related to occurrence of the maximum layers of chlorophyll-a concentration and copepod nauplius densities. Bull Jpn Soc Fish Oceanogr 45: 21-30 (in Japanese with English abstract)

Gorelova TA, Efremenko VN (1989) On the food composition of the larvae of two species of lantern anchovies (Myctophidae) from the Scotia Sea. J Ichthyol 29:106-109

Govoni JJ, Hoss DE, Chester AJ (1983) Comparative feeding of three species of larval fishes in the Northern Gulf of Mexico: Brevoortia patronus, Leiostomus xanthurus, and Micropogonias undulatus. Mar Ecol Prog Ser 13:189-199

Hattori H (1991) Vertical distribution of zooplankton in the warm core off Sanriku (86B) and adjacent Oyashio water, with special reference to copepods record. Bull Hokkaido Natl Fish Res Inst 55:59-77

Hirakawa K, Goto T, Hirai M (1997) Diet composition and prey size of larval anchovy, Engraulis japonicus, in Toyama Bay, southern Japan Sea. Bull Jpn Sea Natl Fish Res Inst 47:67-78

Hopkins TL, Gartner JV Jr (1992) Resource-partitioning and predation impact of a low-latitude myctophid community. Mar Biol 114:185-197

Hunter JR (1977) Behavior and survival of northern anchovy Engraulis mordax larvae. Calif Coop Ocean Fish Invest Rep 19:138-146

Hunter JR (1981) Feeding ecology and predation of marine fish larvae. In: Lasker R (ed) Marine fish larvae: morphology, ecology, and relation to fisheries. Washington Sea Grant Program, Seattle and London, p 33-79

Huruhashi M (1987) Distribution and feeding habits of the myctophid fish. Bull Jpn Soc Fish Oceanogr 51(4):334-339 (in Japanese)

Ida H (1972) Some ecological aspects of larval fishes in waters off Central Japan. Nippon Suisan Gakkaishi 38:981-994 Ikewaki Y, Sawada Y (1991) Food habits of marine fish larvae. 
In: Tanaka M (ed) Early development in fishes. KoseishaKoseikaku, Tokyo, p 86-104 (in Japanese)

Kawaguchi K, Mauchline J (1982) Biology of myctophid fishes (Family Myctophidae) in the Rockall Trough, Northeastern Atlantic Ocean. Biol Oceanogr 1:337-373

Kobari T, Nagaki T, Takahashi K (2004) Seasonal changes in abundance and development of Calanus pacificus (Crustacea: Copepoda) in the Oyashio-Kuroshio mixed region. Mar Biol 144:713-721

Kubota H, Oozeki Y, Kimura R (2001) Horizontal distribution of larvae and juveniles of small pelagic fishes collected by a MIKT at the northern edge of warmer water in the Kuroshio-Oyashio Transition Area in spring. Bull Natl Res Inst Fish Sci 16:57-73 (in Japanese with English abstract)

Loeb VJ (1979a) Vertical distribution and development of larval fishes in the north Pacific central gyre during summer. Fish Bull US 77:777-793

Loeb VJ (1979b) Larval fishes in the zooplankton community of the North Pacific central gyre. Mar Biol 53:173-191

Mauchline J (1998) The biology of calanoid copepods. Adv Mar Biol 33:1-710

Mitani I (1988) Food habits of Japanese anchovy in the shirasu fishing ground within Sagami Bay. Nippon Suisan Gakkaishi 54(11):1859-1865 (in Japanese with English abstract)

Moku M (2000) Ecological study of myctophid fishes in the subarctic and transitional waters of the western North Pacific. PhD thesis, University of Tokyo (in Japanese)

Moku M, Kawaguchi K, Watanabe H, Ohno A (2000) Feeding habits of three dominant myctophid fishes, Diaphus theta, Stenobrachius leucopsarus and S. nannochir, in the subarctic and transitional waters of the western North Pacific. Mar Ecol Prog Ser 207:129-140

Moku M, Tuda A, Kawaguchi K (2003) Spawning season and migration of the myctophid fish Diaphus theta in the western North Pacific. Ichthyol Res 50(1):52-58

Moser HG (1981) Morphological and functional aspects of marine fish larvae. In: Lasker R (ed) Marine fish larvae: morphology, ecology, and relation to fisheries. Washington Sea Grant Program, Seattle and London, p 89-131

Moser HG, Ahlstrom EH (1996) Myctophidae: lanternfishes. In: Moser HG (ed) The early stages of fishes in the California Current region. CalCOFI atlas no. 33, Allen Press, Lawrence, p 387-475

Moser HG, Smith PE (1993) Larval fish assemblages of the California Current region and their horizontal and vertical distributions across a front. Bull Mar Sci 53:645-691

Motoda S (1971) Devices of simple plankton apparatus V. Bull Fac Fish Hokkaido Univ 22(2):101-106

Nishida S, Marumo R (1982) Vertical distribution of cyclopoid copepods of the family Oithonidae in the western Pacific and eastern Indian Oceans. Bull Plankton Soc Jpn 29: 99-118

Odate K (1994) Zooplankton biomass and its long-term variation in the western North Pacific Ocean, Tohoku sea area, Japan. Bull Tohoku Reg Fish Res Lab 56:115-173 (in Japanese with English abstract)

Oozeki Y, Hu F, Kubota H, Sugisaki H, Kimura R (2004) Newly designed quantitative frame trawl for sampling larval and juvenile pelagic fish. Fish Sci 70:223-232

Ozawa T (1986) Early life history of the family Myctophidae in the ocean off southern Japan. In: Ozawa T (ed) Studies on the oceanic ichthyoplankton in the western North Pacific. Kyushu Univ Press, Hukuoka, p 114-187

Ozawa T (1988) Family: Myctophidae. In: Okiyama M (ed) An atlas of the early stage fishes in Japan. Tokai University Press, Tokyo, p 85-91 (in Japanese)
Paxton JR (1967) Biological note on southern California lanternfishes (family Myctophidae). Calif Fish Game 53: 214-217

Paxton JR (1979) Nominal genera and species of lanternfishes (family Myctophidae). Los Angeles Count Mus Nat Hist Contrib Sci 322:1-28

Pearcy WG, Krygier EE, Mesecar R, Ramsey F (1977) Vertical distribution and migration of oceanic micronekton off Oregon. Deep-Sea Res 24:223-245

Pearcy WG, Nemoto T, Okiyama M (1979) Mesopelagic fishes of the Bering Sea and adjacent northern North Pacific Ocean. J Oceanogr Soc Jpn 35:127-135

Pearre S Jr (1986) Ratio-based trophic niche breadths of fish, the Sheldom spectrum, and the size-efficiency hypothesis. Mar Ecol Prog Ser 24:299-314

Pertseva-Ostroumova TA (1964) Some morphological characteristics of myctophid larvae (Myctophidae, Pisces). In: Rass TS (ed) Fishes of the Pacific and Indian Oceans, biology and distribution. Tr Inst Okeanol Akad Nauk SSSR 73:79-97

Sabatés A, Saiz E (2000) Intra-and interspecific variability in prey size and niche breadth of myctophiform fish larvae. Mar Ecol Prog Ser 201:261-271

Sassa C (2001) Ecological study of myctophid fish larvae and juveniles in the western North Pacific. PhD thesis, University of Tokyo (in Japanese)

Sassa C, Kawaguchi K (2004) Larval feeding habits of Diaphus garmani and Myctophum asperum (Pisces: Myctophidae) in the transition region of the western North Pacific. Mar Ecol Prog Ser 278:279-290

Sassa C, Kawaguchi K, Kinoshita T, Watanabe C (2002a) Assemblages of vertical migratory mesopelagic fish in the transitional region of the western North Pacific. Fish Oceanogr 11(4):193-204

Sassa C, Moser HG, Kawaguchi K (2002b) Horizontal and vertical distribution patterns of larval myctophid fishes in the Kuroshio Current region. Fish Oceanogr 11(1):1-10

Sassa C, Kawaguchi K, Mori K (2004a) Late winter larval mesopelagic fish assemblage in the Kuroshio waters of the western North Pacific. Fish Oceanogr 13(2):121-133

Sassa C, Kawaguchi K, Oozeki Y, Kubota H, Sugisaki H (2004b) Distribution patterns of larval myctophid fishes in the transition region of the western North Pacific. Mar Biol 144:417-428

Sassa C, Kawaguchi K, Hirota Y, Ishida M (2004c) Distribution patterns of larval myctophid fish assemblages in the subtropical-tropical waters of the western North Pacific. Fish Oceanogr 13(4):267-282

Shannon CE, Weaver W (1949) The mathematical theory of communication. University of Illinois Press, Chicago

Shirota A (1970) Studies of the mouth size of fish larvae. Bull Jpn Soc Sci Fish 36:353-368 (in Japanese with English abstract)

Takahashi M, Watanabe Y, Kinoshita T, Watanabe C (2001) Growth of larval and early juvenile Japanese anchovy, Engraulis japonicus, in the Kuroshio-Oyashio transition region. Fish Oceanogr 10(2):235-247

Tanaka M (1980) Feeding and survival in marine fish larvae. I. Food organisms of wild larvae. Aquabiology 2(6): 440-447 (in Japanese)

Tsukamoto Y, Zenitani H, Kimura R, Watanabe Y, Oozeki Y (2001) Vertical distribution of fish larvae in the Kuroshio and Kuroshio-Oyashio transition region in early summer. Bull Natl Res Inst Fish Sci 16:39-56

Uotani I (1985) The relation between feeding mode and feeding habit of the anchovy larvae. Bull Jpn Soc Sci Fish 51(7):1057-1065 (in Japanese with English abstract) 
Uotani I, Goto M, Segawa R (1988) Feeding habit of the Japanese anchovy (Engraulis japonicus) during the planktonic life stage. In: Kawaguchi K (ed) Ecological studies on mechanisms of the formation of the 'shirasu' fishing ground. Report for part of the results of Grantin-aid for Cooperative Research (B) in 1987. Ministry of Education, Science and Culture, Tokyo, p 58-66 (in Japanese)

Watanabe H, Moku M, Kawaguchi K, Ishimaru K, Ohno A (1999) Diel vertical migration of myctophid fishes (family Myctophidae) in the transitional waters of the western North Pacific. Fish Oceanogr 8(2):115-127

Watanabe H, Kawaguchi K, Hayashi A (2002) Feeding habits of juvenile surface-migratory myctophid fishes (family

Editorial responsibility: Otto Kinne (Editor-in-Chief), Oldendorf/Luhe, Germany
Myctophidae) in the Kuroshio region of the western North Pacific. Mar Ecol Prog Ser 236:263-272

Wiebe $\mathrm{PH}$, Morton AW, Bradley AM, Backus RH, Craddock JE, Barber V, Cowles TJ, Flierl GR (1985) New developments in the Multiple Opening-Closing Net and Environment Sensing System, an apparatus for sampling zooplankton and micronekton. Mar Biol 87(3):313-323

Willis JM, Pearcy WG, Parin NV (1988) Zoogeography of midwater fishes in the Subarctic Pacific. Bull Ocean Res Inst Univ Tokyo 26 II:79-142

Wisner RL (1976) The taxonomy and distribution of lanternfishes (family Myctophidae) of the eastern Pacific Ocean. Activity report no. 3. Navy Ocean Research and Development, Bay St Louis, MS

Submitted: July 13, 2004; Accepted: May 21, 2005

Proofs received from author(s): July 27, 2005 